\title{
METHODS FOR DETECTING FIRES IN ECOSYSTEMS USING LOW-RESOLUTION SPACE IMAGES
}

\author{
Valerii Shvaiko, Olena Bandurka, Vadym Shpuryk, Yevhen Havrylko \\ The National Technical University of Ukraine "Igor Sikorsky Kyiv Polytechnic Institute", Heat Power Engineer Department, Automation of Projection of Power Processes \\ and Systems, Kyiv, Ukraine
}

\begin{abstract}
The paper presents the methods for fire identification using low-resolution space images obtained from Terra Modis and NOAA satellites. There are lots of algorithms to identify potentially "fire pixels" (PF). They are based on the assessment of temperature in spectral ranges from 3.5-4 to 10.5-11.5 microns. One of the problematic aspects in the Fire Detection Method using low-resolution space images is "Cloud and Water Masking". To identify "fire pixels", it is important to exclude from the analysis fragments of images that are covered with clouds and occupied by water objects. Identification of pixels in which one or more fires are actively burning at the time of passing over the Earth is the basis of the algorithm for detecting potentially "fire pixels". The algorithm requires a significant increase in radiation in the range of 4 micrometers, as well as on the observed radiation in the range of 11 micrometers. The algorithm investigates each pixel in a scene that is assigned one of the following classes as a result: lack of data, cloud, water, potentially fire or uncertain. The pixels that lack actual data are immediately classified as "missing data (NULL)" and excluded from further consideration. Cloud and water pixels, defined by the cloud masking technique and water objects, belong to cloud and water classes, respectively. The fire detection algorithm investigates only those pixels of the Earth's surface that are classified as potentially fire or uncertain. The method was implemented using the Visual Programming Tool PowerBuilder in the data processing system of Erdas Imaging. As a result of the use of the identification method, fires in the Chornobyl exclusion zone, steppe fires and fires at gas wells were detected. Using the method of satellite fire identification is essential for the prompt detection of fires for remote forests or steppes that are poorly controlled by ground monitoring methods.
\end{abstract}

Keywords: environmental security, ecosystem fires in Ukraine, remote sensing, GIS

\section{METODY WYKRYWANIA POŻARÓW W EKOSYSTEMACH PRZY UŻYCIU ZDJĘĆ SATELITARNYCH O NISKIEJ ROZDZIELCZOŚCI}

\begin{abstract}
Streszczenie. W artykule przedstawiono metody identyfikacji pożarów przy wykorzystaniu niskorozdzielczych zdjęć satelitarnych uzyskanych z satelitów Terra Modis i NOAA. Istnieje wiele algorytmów służacych do identyfikacji potencjalnych "pikseli pożaru". Opieraja się one na ocenie temperatury $w$ zakresach spektralnych od 3,5-4 do 10,5-11,5 mikronów. Jednym z problematycznych aspektów metody detekcji pożarów z wykorzystaniem zdjęć satelitarnych o niskiej rozdzielczości jest "maskowanie przez chmury i wodę". Aby zidentyfikować „piksele pożaru” należy wykluczyć z analizy fragmenty zdjęć pokryte chmurami oraz zajęte przez obiekty wodne. Podstawa algorytmu do wykrywania potencjalnych "pikseli pożaru” jest identyfikacja pikseli, $w$ których, w momencie przelotu nad Ziemia, aktywny jest jeden lub większa liczba pożarów. Do prawidtowej pracy, algorytm wymaga znacznego wzrostu poziomu promieniowania w zakresie 4 oraz 11 mikrometrów. Algorytm analizuje każdy piksel zdjęcia $i$ w rezultacie przypisuje mu jedna z następujących klas: brak danych, chmura, woda, potencjalny pożar lub niepewny. Piksele, którym nie sa przypisane rzeczywiste dane, sa natychmiast klasyfikowane jako "brakujace dane (NULL)" i wytączane z dalszej analizy. Piksele należace do chmur $i$ wody, określone dzięki technice maskowania chmur i obiektów wodnych, zaliczane sa odpowiednio do klas chmur $i$ wody. Algorytm detekcji pożaru bada tylko te piksele powierzchni Ziemi, które zostały zaklasyfikowane jako potencjalny pożar lub niepewne. Metoda została zaimplementowana przy użyciu Visual Programming Tool PowerBuilder w systemie przetwarzania danych firmy Erdas Imaging. W wyniku zastosowania metody, wykryto pożary $w$ czarnobylskiej strefie zamkniętej, pożary stepów oraz pożary przy odwiertach gazowych. Zastosowanie metody satelitarnej identyfikacji pożarów jest niezbędne do szybkiego wykrywania pożarów w odlegtych lasach lub stepach, które sa słabo kontrolowane przez naziemne metody monitoringu.
\end{abstract}

Slowa kluczowe: bezpieczeństwo środowiska, pożary ekosystemów na Ukrainie, zdalne wykrywanie, GIS

\section{Introduction}

One of the most dangerous natural phenomena is fires in ecosystems (FE). The most difficult and hazardous are the fires in forests, forest-steppes, steppes, leading to catastrophic consequences to the environment. The increase in the number and scale of such fires, linked to the global warming processes, was not spared Ukraine. Ukraine and Poland have common borders and so we have the same problem.

Ukraine has some experience in assessing such fires.

One way of resolving the technical task on collecting and assessing fire information is Earth remote sensing. This has led to active application of (ERS) methods to obtain fire information, solve above-mentioned tasks in Ukraine. The constant evolution of technical means, ways, high frequency of information, availability and accessibility of (ERS) materials enable us to continue research in this direction and solve interesting scientific problems.

\section{Formulation of the problem}

Space Techniques for Monitoring and Fires in ecosystems help identify them at an early stage and ensure rapid decision making that facilitates the monitoring and impact assessment. The use of space-based data for fire monitoring provides objective and independent information in a timely and cost-effective manner in order to make quick decisions to subdue the elements. The use of space-based imagery not only allows for the detection of fires in some territories but to perform their primary classification according to the scale of combustion, and the use of multispectral data in bands combinations - is to monitor smoke fields of contamination, assess the transport of combustion products.

There are two main sources of fire activity, which are characterized by specific approaches: combustion sources and fire-damaged territories. But the approach to the fire detection is characterized by certain restrictions and can`t be used for spatial fire coverage evaluation, especially since the satellite is often not located at the point necessary for detection at the moment of active combustion, or it is closed from it due to cloudiness. Therefore, there is a need to obtain data on the territories damaged by fire.

Late detection of forest fires have serious consequences for the natural balance of ecosystems. So monitoring of potentially hazardous areas makes it easier to localize and fight fire in an early stage. Remote monitoring of forest fires is rather promising at the present stage. The data on conditions on Earth being obtained from satellites on a regular basis is widely used for operational monitoring of wildfire. At the same time the possibilities of modern technologies make it possible to combine a large amount of other related information. 


\section{Analysis of recent research and publications}

The detailed analysis of recent study and results indicate that the task of defining areas damaged by (FE) through the use of remote-sensing has many alternative solutions.

There are a lot of online services of fire monitoring through the use of remote-sensing data, such as FIRMS [1].

The following satellite systems are being used for monitoring areas damaged by fires:

- Terra satellites with spectra radiometer

- LANDSAT TM/ETM+ satellites.

- NOAA/AVHRR satellites.

Every satellite system should be used for different purposes. LANDSAT is successfully used for detection and control forest fires, for detection of effect of wind storm on forest planting. NOAA and TERRA are important for detection of dangerous organism concentration [2].

Objective and timely information on fire impact is necessary for a wide range of forestry applications, including the conservation and protection of forests, management of forests, and reforestation updating of forest resources data [5]. Data on forest fires cover is a consistent part of information support assessment of direct and secondary pyrotechnic emissions of carbon dioxide and other greenhouse gases to the atmosphere as part of commitments of countries to the Kyoto Protocol, as well as their scientific research on the problems of global climate change and biosphere [4].

Satellite imagery has been used with increased frequency recently that allows to significantly improve the completeness of the detection and the accuracy of defining the area of tree formations, that dry up, which can be a fire risk, especially in summer, as well to more effectively organize ground-based assessment of quantitative characteristics of their conditions $[2,10]$.

Possibility of using satellite data for evaluating the extent of damage caused by forest fires. The research findings in particular showed correlation between the damage level values and the display coefficient value in medium infrared band [10, 12], normalized difference vegetation index and a number of other indices derived from space images. The usefulness of combining different pre- and -post satellite data was noted. Most studies up to now have been local, and were carried out in small areas, often limited to individual fires.

Automatic technologies of satellite monitoring which have been developed up for now ensure a continuous detection and assessment of forest fire damage trough integrated use of MODIS and Landsat -TN/ETM, +data [2].

The use of satellite systems became possible thanks to the use of devices that capture light from different spectra including infrared ones.

Aerospace monitoring provide up-to-date information which is particularly important for conducting a situational analysis for the purpose of making the best decisions. These data are the basis for the development of topographic and thematic maps, actually the primary source of all up-to-date cartographic information.

Moreover, modern technology for aerospace monitoring and remote sensing and computer processing held a great deal of advantage over traditional paper charts-on the content and diversity of visualization methods. According to experts evaluation in the very near term (ERS) Earth Remote Sensing is going to become the main information source for (GIS) while traditional maps will be used only in the initial phase as a source of static information (relief, hydrography, main roads, administrative division). You can also add that practically all computer-based geographic analysis is performed with data in raster form which is characteristic of Earth Remote Sensing. In this study NOAA-AVHRR space imagery were used and are requested by national fire services of many countries (the USA, Canada, Brazil) and have long been used to identify fires and assess their consequences. Despite the fact that the resolution image capability is relatively small $-1100 \mathrm{~m}$, monitoring of heat changes from a pixel makes it possible to identify even forest fires within a small area in hectars, and high-temperature point fire sources. Use the experience of the British Institute of Natural Resources and academic centres of Poland, Chile, Nicaragua, Namibia made it possible to develop and apply a similar method of rapid fire detection in a relatively small area of Chernobyl Exclusion Zone.

\section{The purpose and objectives of this study}

The purpose of this study is to analyze the methods of fire identification using low-resolution space images obtained from Terra Modis and NOAA satellites and determine the directions of information technology development. Consider Methods for detecting fires using low-resolution space images. There are a number of algorithms available to identify potentially fire pixels (PF). They are based on estimates of bright temperature in spectral ranges from $3.5-4$ to $10.5-11.5$ microns.

These algorithms are divided into - threshold and spatial (contextual) groups. Threshold algorithms are sensitive to conditions of a particular terrain, time of year, time of day, type of vegetation, soil temperature, etc. Contextual algorithms are based on comparing the brightness temperature of a potentially fire pixel with bright ness temperature cloudless surrounding pixels. This algorithm takes into account the spatial change of the thermal background, as opposed to the single-band or multiband threshold separation algorithm.

One of the problematic aspects in the Fire Detection Method using low-resolution space images is "Cloud and Water Masking". To identify "fire pixels", it is important to exclude from the analysis fragments of images that are covered with clouds and occupied by water objects.

It is important to divide the analysis methods in the daytime and at night. In the daytime, pixels are considered dimmed if the following condition is true: $\left(\rho_{0.65}+\rho_{0.85}>0.9\right)$ OR $\left(\mathrm{T}_{12}<265 \mathrm{~K}\right)$ OR $\left(\rho_{0.65}+\rho_{0.85}>0.7\right)$ AND $\left(\mathrm{T}_{12}<285 \mathrm{~K}\right)$. Where $\mathrm{T}_{12}$ is the brightness temperature in the spectral range of 11-12 microns, and $\rho_{0.65}$ and $\rho_{0.85}$ are reflective coefficients. At night, pixels were marked as cloud when the condition $\mathrm{T}_{12}<265 \mathrm{~K}$ was met. It found that these simple criteria were sufficient to identify larger, cooler clouds, but did not take into account small clouds and cloud edges.

\section{Algorithm for preliminary detection of potentially "fire" pixels for Modis images}

Identification of pixels in which one or more fires are actively burning at the time of passing the satellite above the Earth is the basis of the algorithm for detecting potentially "fire" pixels: $\mathrm{T}_{4}>310 \mathrm{~K}, \Delta \mathrm{T}>10 \mathrm{~K}, \rho_{0.86}<0.3$, where $\Delta \mathrm{T}=\mathrm{T}_{4}-\mathrm{T}_{11}$, where $T_{4}$ is a bright spectral range of $4 \mu \mathrm{k}, \mathrm{T}_{11}$ is a bright temperature in the spectral range of $11 \mu \mathrm{k}, \rho_{0.86}$ is the reflection coefficient of the sun's um. For night pixels, the reflection test is skipped and the $\mathrm{T}_{4}$ threshold has been reduced to $305 \mathrm{~K}$. Pixels that do not match these previous tests are immediately classified as non-fire pixels. There are two logical paths, through which fire pixels can be identified. The first consists of a simple absolute threshold test. This threshold must be set high enough to trigger only very unambiguous fire pixels, that is, those that cannot become false alarms. The second way consists of a series of developed contextual tests to detect most active fire pixels that are less.

\section{Absolute threshold test}

The absolute threshold criterion remains identical to the original algorithm[4]: $\mathrm{T}_{4}>360 \mathrm{~K}$ (> $320 \mathrm{~K}$ at night). Despite the high daytime threshold, the usefulness of this test depends on the angle of reflection of sunlight above the horizon, otherwise false alarms caused by the glare of certain objects may occur. 


\section{Background algorithm}

The next step of the algorithm, which is performed regardless of the result of the absolute threshold test, is an attempt to use neighboring pixels to assess the radiometric signal of a potential "fire" pixel. Real pixels are used as background values in the window, decentralized is a pixel identified as potentially "fire". In this window, pixels that are considered to be valid are considered to be:

1) contain useful observations;

2) are located on land;

3) not contaminated with clouds;

4) are not background "fire" pixels.

"Fire" pixels are defined as having $\mathrm{T}_{4}>325 \mathrm{~K}$ and $\Delta \mathrm{T}>20 \mathrm{~K}$ for day observations, or $\mathrm{T}_{4}>310 \mathrm{~K}$ and $\Delta \mathrm{T}>10 \mathrm{~K}$ for night observations

An important factor in this algorithm is the size of the window. Empirically expedient is a size of $21 \times 21$ pixels, with validity of at least 8 pixels.

The number of actual pixels in the background window is $N_{v}$. During the analysis process, the number of adjacent pixels $\left(N_{f}\right)$ is determined, as well as the number of adjacent pixels excluded as water $\left(N_{w}\right)$.

If a sufficient number of real adjacent pixels is identified, several statistical indicators are calculated statistical indicators. This is $\overline{\mathrm{T}_{4}}$ and $\sigma_{4}$, the corresponding mean and the average absolute deviation of $\mathrm{T}_{4}$ for real adjacent pixels. $\overline{\mathrm{T}_{11}}$ and $\sigma_{11}$ corresponding mean and absolute deviation of $\mathrm{T}_{11}$ for real adjacent pixels; $\overline{\Delta \mathrm{T}}$ and $\sigma \Delta \mathrm{T}$ corresponding to the mean and average for real adjacent pixels.

For contextual fire detection algorithms, the average absolute deviation is used as a measure of dispersion rather than standard deviation, since it is more resistant to deviations. This is very desirable, since pollution of the background window with uncertain clouds, water, fires and other sources is not uncommon.

\section{Contextual algorithm for identifying fire pixels using NOAA AVHHR images}

Contextual algorithm that identifies "fire" pixels results in two consecutive tests:

Test 1: pixel selected as "fire" if:

$$
\begin{aligned}
& \mathrm{T}^{\mathrm{B}}(3)>311 \mathrm{~K}[1], \\
& \mathrm{T}^{\mathrm{B}}(3)-\mathrm{T}^{\mathrm{B}}(4)>8 \mathrm{~K}[2],
\end{aligned}
$$

Test 2: The pixel is confirmed as "fire", if:

$$
\begin{aligned}
& \mathrm{T}^{\mathbf{B}}(3-4)_{\mathrm{PF}}-\left[\mathrm{T}^{\mathbf{B}}(3-4)_{\mathrm{b}}+\delta \mathrm{T}^{\mathbf{B}}(3-4)_{\mathrm{b}}\right]>0[3], \\
& \mathrm{T}^{\mathbf{B}}(3)_{\mathrm{PF}}-\left[\mathrm{T}^{\mathbf{B}}(3)_{\mathrm{b}}+\delta \mathrm{T}^{\mathbf{B}}(3)_{\mathrm{b}}\right]>3 \mathrm{~K}[4],
\end{aligned}
$$

where $\mathrm{T}^{\mathbf{B}}(3)_{\mathrm{b}}$ - the average value of the bright background temperature in band $3, \delta \mathrm{T}^{\mathbf{B}}(3)_{\mathrm{b}}$ - standard deviation of the bright background temperature in the band $3, T^{\mathbf{B}}(3-4)_{b}-$ the average value of the difference in bright temperature (band 3 - band 4 ), $\delta \mathrm{T}(3-4)_{\mathrm{b}}-$ standard deviation of the difference in bright temperature (band 3 - band 4 ).

The pixels selected in this way can be divided into three groups: definitely firefighters, probably firefighters and unambiguously non-fire. Further determination of unambiguously fire pixels is carried out by masking places where PF is uniquely inseparable (sandy soils, reservoirs, man-made objects that emit a large amount of heat).

The presence of clearly defined areas with a high degree of fire danger (maps of forest quarters in the forest areas of the exclusion zone with certain characteristics of the state of forests) makes it possible to attribute PF do to unambiguousfire pixels with a high probability.

Implementation of the fire identification algorithm. The method was implemented with the help of the Visual Programming Tool PowerBuilder in the data processing system of remote sensing Erdas Imaging. The algorithm of implementation of this method is shown in Figure 1.

Fire monitoring should be carried out by a sequence of operations in the environment of the ERDAS remote sensing system. This sequence can be divided into several stages:

1) acquisition and adaptation of space imagery

2) PF identification according to criteria 1-

3) geometric correction of the image

4) integration of the snapshot with cartographic data and interpretation of the results.

Reception stations receive NOAA AVHRR pictures in HRPT format. Specialized program SmartTrack AVHRR snapshot is converted to intermediate Level1B format, and Import ErdasImagine module intermediate file is converted to the working format of the system ErdasImagine.

During import, radiometric correction (data calibration) is performed. The result of this processing stage is a fragment of an imported image covering the territory of Ukraine and adjacent regions of other countries (Figure 2).

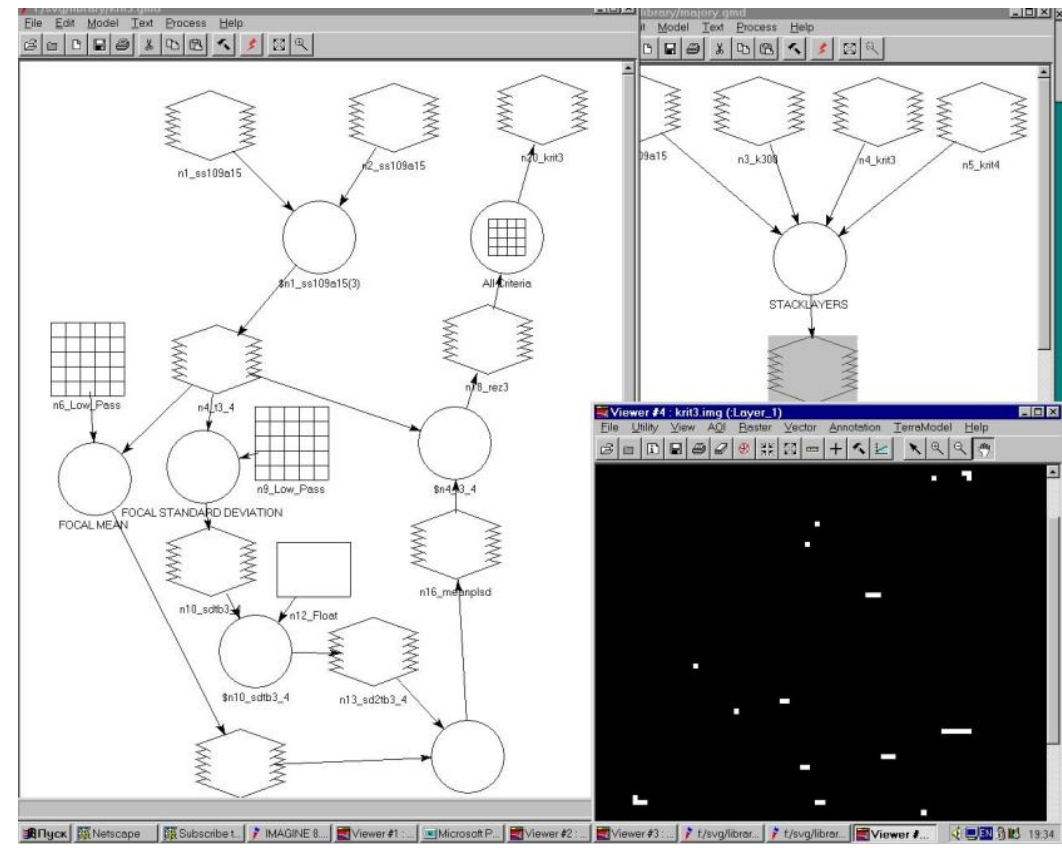




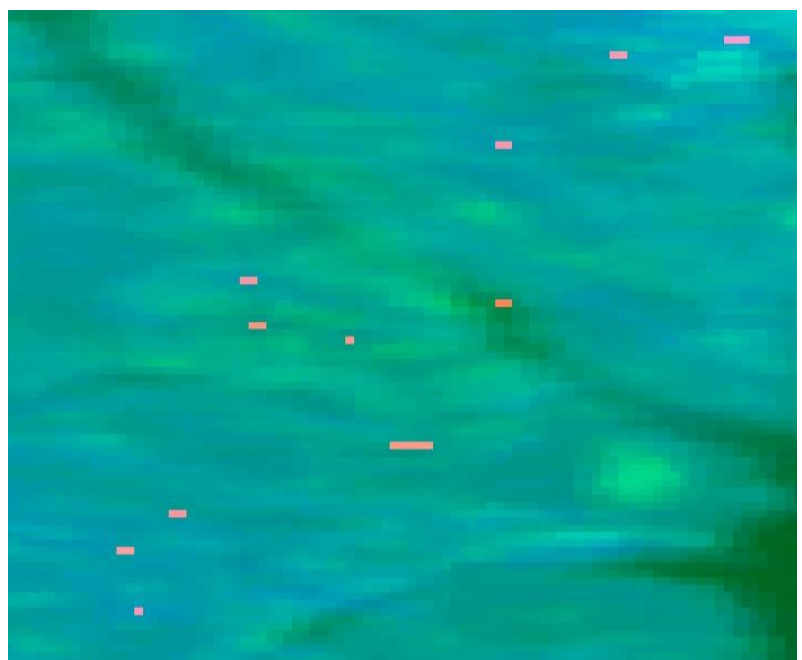

Fig. 2. Potentially fire pixels

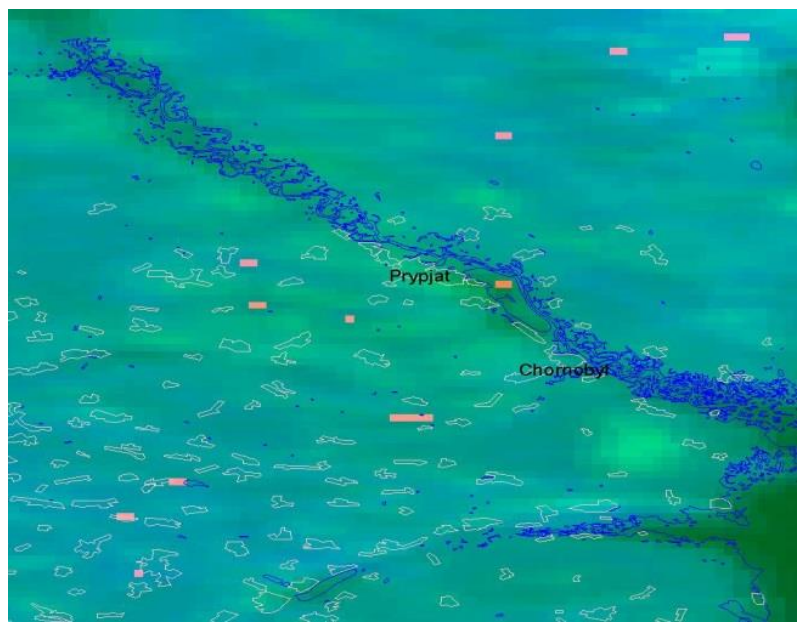

Fig. 3. Rectified image is combined with a vector layer of reservoirs

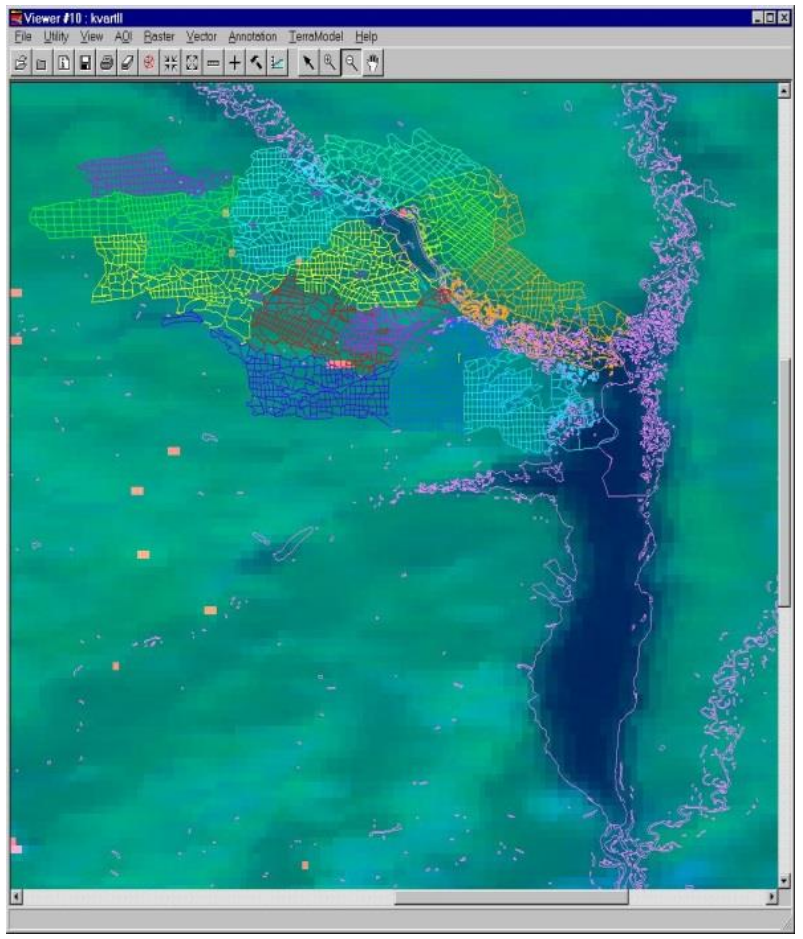

Fig. 4. Identification of the potentially fire pixels of the summaries from the map of the forest quarters
For PF identification as part of the model project (ModelMaker package procedures - Erdas Imagine module), that implement the criteria 1-3, and so-as-cloud masking models (deleting from analysis area)

The process of allocating fires has the following sequence of actions: Selecting pixels according to criterion [1] - selection of pixels with a bright $>311 \mathrm{~K}$.

The selection of pixels according to the criterion [2] - selection of pixels by temperature difference in band 3 and 4 . Potentially fire pixels highlighted in the second stage appear bright red in the picture (Figure 3). The selection of pixels according to the criterion [3] - statistical assessment of the difference between brightness temperatures in band 3 and 4 . Selection of pixels according to the criterion [4] - statistical assessment of the temperature in band 3 .

The result of these four stages will be pictures on which potentially fire pixels will be allocated. The intersection of all four criteria shows us with a fairly high probability of having fires in the area under study. As a result, we will get a picture with the identified fires.

Geometric correction of the image After identifying fires, it is necessary to determine the exact localization (in this project, the binding with accuracy to the forest quarter is sufficient). To do this, the picture must be corrected (rectified) and brought to the cartographic projection, which contains the main cartographic data associated with the Chornobyl exclusion zone.

This process was carried out by identifying the anchor points in the picture and matching them with objects on a vector map Geometric correction was carried out on the basis of the method of polynomial transformation of the second order. Figure 4 shows the following picture. The quality of geometric correction is visible in combination with the vector layer of water surfaces.

Obtaining information based on the processing of SES data during May and June, the above-mentioned method was tested on fragments of images of the exclusion zone. Composite time series of snapshot fragments. On the basis of this technique, several constantly "hot" objects were found in the zone (these are heated sandy soils near the Uzh River, the RV storage facility near Buriakivka village and a number of others.

\section{Conclusions}

The problem of fires in recent years attracts special attention in the context of the growing influence of such global processes as the reduction of the world's forest areas, the loss of biodiversity, global climate change and land use changes. This is due to the complexity and ambiguity of the impact of fires on forests, environments and communities living around forests. Determining the areas of forests covered by fires is an important component of the information support of forestry. The method proposed in this work, which is based on a combination of medium infrared (3-4 microns) with thermal (10-11 micron) NOAA AVHRR space images, allows you to quickly determine the fire in real time at the sub-pixel level. Prompt detection of fires makes it possible to quickly extinguish fires and save forest resources. An example of this method was carried out on the fires of the Chornobyl Exclusion Zone and fires at gas wells in the Poltava region of Ukraine.

To quickly determine the fire in real time at the subpixel level. Prompt detection of fires makes it possible to quickly extinguish fires and save forest resources. An example of this method was carried out on the fires of the Chornobyl Exclusion Zone and fires at gas wells in the Poltava region of Ukraine.

This method is universal and requires only high-quality NOAA AVHRR space images, Terra Modis, which is freely available. 


\section{References}

[1] Chandra A. M., Gosh S. K.: Remote sensing and geographic information systems. Tecnosfera, Moscow 2008

[2] Griffiths P. et al.: Forest disturbances, forest recovery, and changes in fores types across the Carpathian ecoregion from 1985 to 2010 based on Landsat image composites. Remote Sensing of Environment 151/2014, 72-88.

[3] Justice C. O. et al.: Robust statistics. Wiley, New York 2002.

[4] Kaufman Y. J., Justice C. O., Flynn L. P., Kendall J. D., Prins E. M., Giglio L. Ward D. E., Menzel W. P., Setzer A. W.: Potential global fire monitoring from EOS-MODIS. Journal of Geophysical Research 103(D24)/1998, 32215-32238.

[5] Kashkin V. B., Suchinin A. I.: Remote sensing of the Earth from space. Digital imaging. Logos, Moscow 2001.

[6] Krycuk S. G.: Mapping boreal forests using satellite data. Modern problems of remote sensing of the Earth from space 9(4)/2012, 255-264.

[7] Morisette J. T. et al.: Identification of subresolution high temperature sources using a thermal IR sensor. Photogrammetric Engineering and Remote Sensing 47/2003, 1311-1318

[8] Morissette, J. T. et al.: Validation of the MODIS active fire product over Southern Africa with ASTER data. International Journal of Remote Sensing 26(19)/2002, 4239-4264.

[9] Seielstad C. A. et al.: MODIS level 1A Earth location: Algorithm theoretical basis document version 3.0. SDST-092, MODIS Science Data Support Team 2002

[10] Stroppiana D. et al.: Testing the sensitivity of a MODIS-like daytime active fire detection model in Alaska using NOAA/AVHRR infrared data Photogrammetric Engineering and Remote Sensing 68/2000, 831-838.

[11] Strugailo V. V.: Review of methods of filtering and segmentation of digita images. Science and education 5/2012, 270-281.

[12] Vyshnjakov V. J., Tkachuk P. A.: Features of methods for determining temperature anomalies according to remote sensing MODIS (TERRA) an AVHRR (NOAA). Estimates of their quality. Ecological safety and nature management 10/2012, 81-90.

[13] Zibcev S. V., Myronjuk V. V.: Methodical recommendations from MODIS and Landsat for monitoring of forest fires: Recommendations for forestry enterprises. NUBandN, Kiev 2015.
M.Sc. Valerii Shvaiko

e-mail: valshvaiko57@gmail.com

Valerii Shvaiko is currently lecturer Departmen Automation of Design of Energy Processes an Systems, National Technical University of Ukraine "Igor Sikorsky Kyiv Polytechnic Institute", Kyiv, Ukraine. Research interests - geoinformation system, remote sensing, civil protection of the population.

http://orcid.org/0000-0002-9304-8710

\section{M.Sc. Olena Bandurka}

e-mail: o.i.bandurka@ukr.net

Olena Bandurka is currently postgraduate student the Department Automation of Design of Energy Processes and Systems, National Technical University of Ukraine "Igor Sikorsky Kyiv Polytechnic Institute", Kyiv, Ukraine. Research interests - knowledge-based geospatial analysis techniques for prediction and assessment of impact on biological environment.

\section{http://orcid.org/0000-0002-8059-1861}

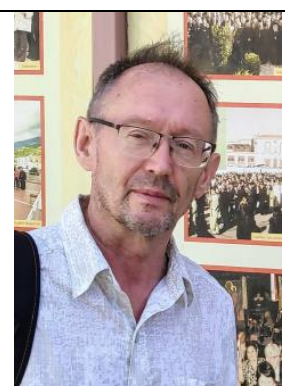

Ph.D. Vadym Shpuryk

e-mail:wadimoff@gmail.com

Ph.D. doctoral supervisor, associate professor of the Department of Computer Aided Design at National Technical University, Ukraine. Engaged in the research of artificial intelligence, GIS technology, underwater sonar signal processing and data processing algorithms. A dedicated system professional and software developer with $25+$ years of technology development and management experience. Programmer/Analyst with solid background in all phases of software development life cycle of various applications.

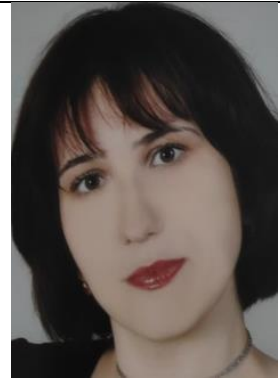

http://orcid.org/0000-0002-3477-573

Prof. Yevhen V. Havrylko

e-mail: gev.1964@ukr.net

Doctor of Engineering Sciences, Professor, Professo department Automation of Design of Energy Processes and Systems, National Technical University of Ukraine "Igor Sikorsky Kyiv Polytechnic Institute", Kyiv, Ukraine.

Research interests - ecological safety, civil protection of the population, remote sensing of the Land, systems of satellite telecommunications.

http://orcid.org/0000-0001-9437-3964

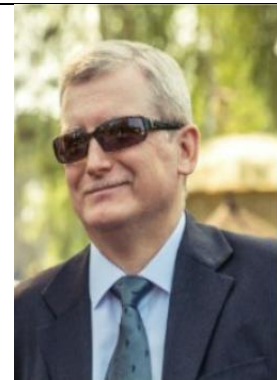

